\title{
Pengaruh Dukungan Pendidikan Dan Dukungan Relasi Terhadap Intensi Berwirausaha Mahasiswa Kepercayaan Diri Sebagai Variabel Moderator
}

\author{
Juan Althea dan Franky Slamet \\ Program Studi S1 Manajemen Fakultas Ekonomi, Universitas Tarumanagara, Jakarta \\ Email:juanalthea@gmail.com
}

\begin{abstract}
The purpose of this research is to examine whether: 1) educational support can affect entrepreneurial intention 2) relational support can affect entrepreneurial intention 3) self-confidence moderates the relationship between educational support and entrepreneurial intentions 4) Self-confidence moderates the relationship between relational support and entrepreneurial intentions. Sample was selected using nonprobability sampling technique to 125 respondents of university students. Data were measured by Likert scale and analyzed with processing techniques using SmartPLS 3.0 program. The result of this study shows that 1) educational support positively had affect on entrepreneurial intention 2) relational support positively had affect on entrepreneurial intention 3) self-confidence weaken the relationship between educational support with entrepreneurial intentions and 4) confidence strengthens the relationship between relationship support and entrepreneurial intentions. Several recommendations for research are presented based on conclusions and suggestions on the results of this study.
\end{abstract}

Keywords: Educational support, relation support, self confidence and entrepreneurship intention.

Abstrak: Tujuan dari penelitian ini adalah untuk menguji apakah: 1) dukungan pendidikan dapat mempengaruhi intensi berwirausaha, 2) dukungan relasi dapat mempengaruhi intensi berwirausaha, 3) kepercayaan diri memoderasi hubungan antara dukungan pendidikan dengan intensi berwirausaha, dan 4) kepercayaan diri memoderasi hubungan antara dukungan relasi dengan intensi berwirausaha. Sampel dipilih menggunakan teknik nonprobability sampling dengan jumlah 125 responden mahasiswa. Data diukur dengan skala Likert dan dianalisis dengan teknik proses yang menggunakan program SmartPLS 3.0. Secara keseluruhan, hasil penelitian ini menunjukkan bahwa 1) dukungan pendidikan berpengaruh positif terhadap intensi berwirausaha, 2) dukungan relasi berpengaruh positif terhadap intensi berwirausaha, 3) kepercayaan diri memperlemah hubungan antara dukungan pendidikan dengan intensi berwirausaha, dan 4) kepercayaan diri memperkuat hubungan antara dukungan relasi dengan intensi berwirausaha. Beberapa rekomendasi untuk penelitian disajikan berdasarkan kesimpulan dan saran mengenai hasil penelitian ini.

Kata kunci: Dukungan pendidikan, dukungan relasi, kepercayaan diri, dan intensi berwirausaha.

\section{LATAR BELAKANG}

Perekonomian Indonesia yang terus meningkat bisa dilihat dari berkurangnya jumlah pengangguran dari tahun ke tahun. Dalam setahun terakhir, pengangguran berkurang 40 ribu 
orang, sejalan dengan TPT (Tingkat Pengangguran Terbuka) yang turun menjadi 5,34 persen pada Agustus 2018 (BPS, 2018). Namun menurut data BPS, generasi muda adalah penyumbang angka pengangguran yang paling tinggi di Indonesia. Berdasarkan data dari Sakernas BPS, jumlah penggangguran generasi muda dari rentang umur 15-24 tahun menunjukkan angka yang lebih tinggi di perkotaan dibandingkan di perdesaan, jumlah pengangguran generasi muda di perkotaan sebesar 22,9 persen, sedangkan pengangguran di desa sebesar 17,2 persen.

Untuk mengatasi tingginya persentase TPT (Tingkat Pengangguran Terbuka) generasi muda, pemerintah memasukkan kurikulum pendidikan kewirausahaan ke dalam lembaga pendidikan, karena pendidikan kewirausahaan dapat membantu meningkatkan niat, rasa percaya diri, dan motivasi seseorang untuk membuka lapangan kerja atau berwirausaha (Bappeda, 2010).

Dengan dukungan pendidikan kewirausahaan, diharapkan mahasiswa mempunyai kemampuan untuk menciptakan, menyediakan dan menjalankan usaha dengan produk yang memiliki nilai tambah dan inovatif sehingga dapat bermanfaat. Untuk itu diperlukan adanya pemahaman tentang bagaimana mengembangkan dan mendorong lahirnya wirausaha muda yang berpotensi. Kewirausahaan adalah faktor kunci untuk pembangunan ekonomi, itu dianggap sebagai faktor yang sangat penting untuk kemajuan pertumbuhan ekonomi, baik di negara maju maupun negara berkembang (Stel dkk., 2005).

Namun, walaupun berwirausaha dapat membantu meningkatkan perekonomian negara dengan menciptakan banyak lapangan pekerjaan baru, masih terdapat banyak generasi muda yang belum memiliki minat untuk berwirausaha karena berbagai hal. Menurut Hamidon (2012), banyak generasi muda yang merupakan lulusan perguruan tinggi kurang memiliki minat untuk menjadi seorang wirausaha karena dianggap sebagai tugas yang menantang. Niat berwirausaha dapat didefinisikan sebagai keterlibatan niat seseorang untuk memulai bisnis baru (Dinis dkk., 2013). Intensi ini disatukan dengan perilaku dan komitmen individu yang termotivasi atau didorong untuk memulai usaha baru (Gerba, 2012). Menurut Turker dan Selcuk (2009) terdapat beberapa faktor yang mempengaruhi intensi berwirausaha yaitu pendidikan kewirausahaan, dukungan relasi dan kepercayaan diri.

Beberapa studi menjelaskan bahwa pendidikan kewirausahaan berperan penting dalam menumbuhkan semangat mahasiswa untuk berwirausaha. Berdasarkan studi yang dilakukan oleh Robb dan Fairlie (2006) menunjukkan bahwa 50 persen dari bisnis baru cenderung gagal di tahun pertama mereka, karena kurangnya persiapan beberapa faktor kunci. Menumbuhkan dan mengembangkan jiwa dalam berperilaku berwirausaha merupakan salah satu faktor penting dan faktor yang sangat berpengaruh di dalam pendidikan kewirausahaan (Indarti \& Rostiani, 2008).

Menurut Henderson \& Robertson (2000), faktor pendukung lainnya adalah dukungan relasi. Studi kewirausahaan telah menetapkan bahwa dukungan dari keluarga dan temanteman memiliki peran yang sangat berpengaruh terhadap intensi berwirausaha. Dukungan dari keluarga dan teman-teman bisa dalam bentuk dukungan emosional maupun dukungan akses modal (Baughn dkk., 2006). Menurut Ismail (2009), jika seorang mahasiswa mengetahui bahwa ia memiliki dukungan kuat dari orang tua dan anggota keluarga mereka, dan juga memiliki akses informasi bisnis, kesediaan mereka untuk menjelajah ke bisnis baru akan cenderung meningkat, sehingga dapat meningkatkan kepercayaan diri mereka.

Bray dkk., (2016) \& Twibell dkk., (2008) menyatakan bahwa dampak dari kepercayaan diri seseorang mampu mengatasi kemampuan mahasiswa dalam menghadapi segala macam situasi. Turker dan Selcuk (2009) menjelaskan bahwa literatur yang ada telah 
membentuk hubungan antara intensi kewirausahaan dan faktor pribadi termasuk kepercayaan diri, pengambilan risiko, locus of control, dan kebutuhan pencapaian. Thompson (1999) mengatakan bahwa kewirausahaan merupakan perilaku bawaan dari dalam diri seseorang yang percaya bahwa pendidikan yang didapatkan dan dilakukan dapat dirangsang melalui sebuah dukungan, seperti tingkat pendidikan, dukungan relasi dari keluarga dan teman juga dapat meningkatkan rasa percaya diri seseorang untuk mencapai sebuah keberhasilan.

Berdasarkan hal-hal yang dijelaskan sebelumnya, penelitian ini dibuat dengan tujuan untuk mengetahui pengaruh dukungan pendidikan, dukungan relasi dan kepercayaan diri terhadap intensi berwirausaha mahasiswa.

\section{KAJIAN TEORI}

Theory of Planned Behavior (TPB) dari Ajzen (1991) merupakan teori yang mendasari penelitian ini. Theory of Planned Behavior (TPB) pada dasarnya merupakan perluasan dari Theory of Reasoned Action (TRA) yang mencakup ukuran keyakinan kontrol dan kontrol perilaku yang dirasakan. Kolvereid (1997) menunjukkan bahwa kerangka kerja Theory of Planned Behavior (TPB) dari Ajzen (1991) adalah model yang kuat untuk menjelaskan atau memprediksi niat kewirausahaan. Ajzen (1991) menyatakan bahwa niat seseorang adalah sesuatu yang langsung berasal dari perilaku. Dalam model TPB, perilaku kewirausahaan individu dipahami sebagai hasil dari niat dan niat yang merupakan fungsi dari tiga komponen yaitu sikap (Attitude), norma subjektif (Subjective Norm), dan kontrol perilaku (Perceived Behavioral Control)

Menurut Lafuente (2014), dukungan pendidikan adalah "A set of initiatives designed to improve national economic development through constant investment in quality education bolstered by an adequate number of teachers and relevant learning tools." Bedasarkan definisi tersebut, dapat disimpulkan bahwa, dukungan pendidikan adalah serangkaian inisiatif yang dirancang untuk membantu meningkatkan pembangunan ekonomi nasional melalui investasi dalam pendidikan berkualitas, yang didukung oleh sejumlah pengajar yang memadai dan alat pembelajaran yang relevan. Cho dan Lee (2018) mengemukakan bahwa program pendidikan kewirausahaan adalah program yang memberikan siswa pengetahuan dasar dan keterampilan untuk kewirausahaan tetapi juga membuat siswa memiliki sikap positif terhadap kewirausahaan.

Yurtkoru (2014) menjelaskan bahwa dukungan relasi adalah "which indicates the sentimental and monetary supports of family and friends, may encourage people to engage in entrepreneurial activities" Artinya, dukungan relasi menunjukkan dukungan sentimental dan moneter dari keluarga dan teman yang dapat mendorong seseorang untuk terlibat dalam kegiatan kewirausahaan. Menurut Baughn dkk., (2006), dukungan relasi adalah dalam bentuk dukungan emosional dan akses ke modal dari teman dan keluarga.

Be 'nabou dan Tirole (2002) menyatakan bahwa, "Self-confidence is valuable because "it makes people happier", "it makes it easier to convince others (rightly or wrongly)" and improves "the individual's motivation to undertake projects and persevere in the pursuit of his goals. "Artinya, kepercayaan diri sangatlah berharga karena dapat membuat seseorang lebih bahagia, lebih mudah untuk meyakinkan orang lain (secara baik atau salah), dan meningkatkan motivasi mereka untuk bertahan dalam mengejar tujuannya. Menurut Twibell dkk., (2008), kepercayaan diri adalah perasaan manusia yang percaya pada kualitas, kemampuan dan penilaiannya terhadap dirinya. 
Dell (2008) menyatakan bahwa, "Entrepreneurial intention is defined as the intention to be self-employed." Artinya intensi berwirausaha adalah sebuah niat untuk menjadi wirausaha.

Souritaris dkk., (2007) menyatakan bahwa, intensi berwirausaha adalah indikasi seseorang yang ingin memulai sesuatu.

Berdasarkan uraian tersebut maka terbentuk kerangka pemikiran dan hipotesis. Model kerangka pemikiran dan hipotesis diuraikan sebagai berikut:

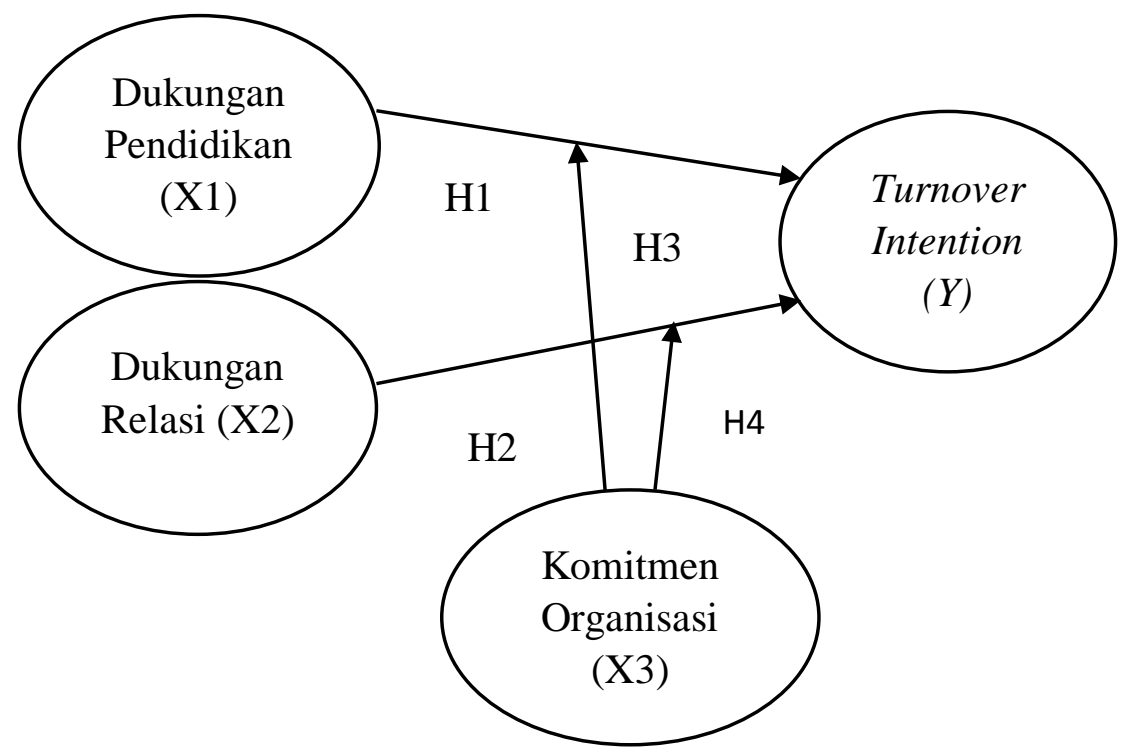

Gambar 1. Kerangka Pemikiran

Berdasarkan kerangka pemikiran di atas, maka dapat dirumuskan hipotesis penelitian sebagai:

H1: Terdapat pengaruh positif antara dukungan pendidikan terhadap intensi berwirausaha mahasiswa.

$\mathrm{H} 2$ : Terdapat pengaruh positif antara dukungan relasi terhadap intensi berwirausaha mahasiswa.

H3: Kepercayaan diri tidak memoderasi hubungan antara dukungan pendidikan dengan intensi berwirausaha mahasiswa.

H4: Kepercayaan diri tidak memoderasi hubungan antara dukungan relasi dengan intensi berwirausaha mahasiswa.

\section{METODOLOGI}

Penelitian ini merupakan penelitian kuantitatif dengan menggunakan desain penelitian deskriptif karena memuat informasi penelitian sebelumnya dengan variabel yang sama dan hipotesis dalam penelitian ini sudah dapat dirumuskan. Populasi yang dijadikan sebagai subjek penelitian ini adalah mahasiswa/i aktif S1 (Sarjana). Metode pengambilan sampel yang akan digunakan dalam penelitian ini adalah metode nonprobability sampling dengan judgemental sebagai teknik pemilihan sampelnya. Sekaran \& Bougie (2013:269) juga mengemukakan bahwa ukuran sampel yang lebih besar dari 30 dan kurang dari 500 adalah jumlah yang tepat untuk kebanyakan penelitian. Penelitian ini mengambil sampel sebanyak 125 responden dengan kriteria yaitu merupakan mahasiswa/i aktif S1 (Sarjana) 
Fakultas Ekonomi Universitas Tarumanagara yang telah menempuh mata kuliah kewirausahaan.

Berdasarkan data yang didapat dari 125 (100\%) responden, 84 orang $(67,2 \%)$ merupakan pria dan responden wanita berjumlah 41 orang $(32,8 \%)$. Kemudian, mayoritas responden berdomisili di Jakarta, yaitu sebesar 104 (83,2\%) diikuti dengan Depok sebanyak $6(4 \%)$ responden dan Bandung sebanyak $3(2,4 \%)$ responden. Penelitian ini menerapkan penggunaan skala Likert sebagai pemberian skor dari setiap indikator dan penyebaran kuesioner dilakukan secara online melalui internet dengan menggunakan google form. Menurut Burns dan Bush (2014:208) skala Likert menjelaskan intensitas seberapa setuju atau tidaknya responden terhadap butir-butir pernyataan yang dapat dilihat dari lima poin skala yang ada (sangat tidak setuju - sangat setuju).

\section{Hasil Uji Statistik}

Hair dkk. (2011) dan Henseler dkk. (2009) menyatakan bahwa uji validitas dapat dilakukan dengan cara mengevaluasi convergent validity dan discriminant validity dalam model penelitian tersebut. Convergent validity diuji dengan menggunakan loading factor dari setiap indikator dan average extracted variance (AVE) dari setiap variabel.

Tabel 1. Hasil Nilai Average Variance Extracted (AVE)

\begin{tabular}{|c|c|}
\hline Variabel & Average Variance Extracted (AVE) \\
\hline Dukungan Pendidikan & 0,678 \\
\hline Dukungan Relasi & 0,865 \\
\hline Intensi Berwirausaha & 0,693 \\
\hline Kepercayaan Diri & 0,738 \\
\hline
\end{tabular}

Hasil uji validitas konvergen dengan menggunakan AVE yang didapatkan menunjukkan bahwa semua variabel yang digunakan dalam penelitian ini adalah valid, dengan nilai dukungan pendidikan sebesar 0,678, dukungan relasi sebesar 0,865, kepercayaan diri sebesar 0,693 dan intensi berwirausaha sebesar 0,738. Hasil ini menunjukkan bahwa setiap variabel di atas telah memenuhi kriteria dengan nilai AVE yang lebih besar dari 0,5 (Hair dkk., 2011). Selanjutnya, suatu indikator dinyatakan valid jika mempunyai loading factor di atas 0.7 terhadap konstruk yang dituju, apabila dalam sebuah model penelitian terdapat indikator yang memiliki nilai loading factor di bawah 0,7 , maka indikator tersebut harus dihilangkan (Henseler dkk., 2009).

Tabel 2. Hasil Nilai Loading Factor

\begin{tabular}{|c|c|c|c|c|}
\hline Indikator & $\begin{array}{c}\text { Dukungan } \\
\text { Pendidikan }\end{array}$ & $\begin{array}{c}\text { Dukungan } \\
\text { Relasi }\end{array}$ & $\begin{array}{c}\text { Kepercayaan } \\
\text { Diri }\end{array}$ & $\begin{array}{c}\text { Intensi } \\
\text { Berwirausaha }\end{array}$ \\
\hline ES1 & 0,819 & & & \\
\hline ES2 & 0,905 & & & \\
\hline ES3 & 0,736 & & & \\
\hline ES4 & 0,833 & & & \\
\hline ES5 & 0,786 & & & \\
\hline ES6 & 0,887 & & & \\
\hline
\end{tabular}




\begin{tabular}{|c|l|l|l|l|}
\hline ES7 & 0,787 & & & \\
\hline RS1 & & 0,928 & & \\
\hline RS2 & & 0,955 & & \\
\hline RS3 & & 0,906 & & \\
\hline SCF1 & & & 0,864 & \\
\hline SCF2 & & & 0,857 & \\
\hline SCF3 & & & 0,869 & \\
\hline SCF4 & & & 0,771 & \\
\hline SCF5 & & & 0,714 & \\
\hline SCF6 & & & 0,915 & \\
\hline SCF7 & & & 0,928 & \\
\hline SCF8 & & & 0,912 & \\
\hline SCF9 & & & 0,879 & \\
\hline EI1 & & & & 0,742 \\
\hline EI2 & & & & 0,848 \\
\hline EI3 & & & & 0,815 \\
\hline EI4 & & & & 0,789 \\
\hline EI5 & & & & 0,892 \\
\hline EI6 & & & & \\
\hline
\end{tabular}

Berdasarkan hasil dari Tabel 2, telah menunjukkan bahwa seluruh indikator memiliki nilai loading factor di atas 0,6 di mana telah memenuhi syarat convergent validity (Hair dkk., 2011), sehingga dapat disimpulkan bahwa semua variabel yang ada dalam penelitian ini telah memenuhi kriteria convergent validity. Dalam pengujian discriminant validity, nilai FornellLarcker yang dimiliki oleh masing-masing variabel pada penelitian ini memenuhi kriteria karena nilai akar kuadrat AVE lebih besar daripada korelasi antar konstruk serta nilai crossloadings masing-masing indikator setiap variabel lebih besar dari nilai cross-loadings variabel lainnya. Berdasarkan hasil analisis convergent validity maupun discriminant validity, maka dapat disimpulkan bahwa variabel dan indikator yang digunakan dalam penelitian ini valid.

Tabel 3. Hasil Uji Reliabilitas

\begin{tabular}{|c|c|c|}
\hline Variabel & Cronbach Alpha's & $\begin{array}{c}\text { Composite } \\
\text { Realibility }\end{array}$ \\
\hline Dukungan Pendidikan & 0,920 & 0,936 \\
\hline Dukungan Relasi & 0,922 & 0,950 \\
\hline Intensi Berwirausaha & 0,910 & 0,931 \\
\hline Kepercayaan Diri & 0,955 & 0,962 \\
\hline
\end{tabular}

Sumber: Pengolahan Data SmartPLS 3.0

Hasil uji Reliabilitas dengan menggunakan Cronbach's alpha dalam variabel dukungan pendidikan adalah sebesar 0,920, variabel dukungan relasi sebesar 0,922, variabel 
kepercayaan diri sebesar 0,910 dan variabel intensi berwirausaha sebesar 0,955 . Nilai tersebut menunjukkan bahwa variabel-variabel yang digunakan dalam penilitian ini adalah reliabel. Karena telah memenuhi nilai rule of thumbs Cronbach's alpha dalam uji reiliabilitas yaitu >0,7 (Henseler et al., 2009).

Hasil uji Reliabilitas dengan menggunakan composite reliability dalam variabel dukungan pendidikan adalah sebesar 0,936, variabel dukungan relasi sebesar 0,950 , variabel kepercayaan diri sebesar 0,931 dan variabel intensi berwirausaha sebesar 0,962. Nilai tersebut menunjukkan bahwa variabel-variabel yang digunakan dalam penilitian ini adalah reliabel. Karena telah memenuhi nilai rule of thumbs composite reliability dalam uji reiliabilitas yaitu >0,7 (Henseler et al., 2009).

Setelah pengujian outer model (validitas dan reliabilitas), pengolahan data variabelvariabel penelitian dilanjutkan pada tahapan pengujian inner model (model struktural) untuk dapat mengetahui kontribusi dari variabel-variabel independen (X) terhadap variabelvariabel dependen (Y). Kriteria pengujian model struktural yang harus dipenuhi pada penelitian ini yaitu nilai koefisien determinasi $\left(\mathrm{R}^{2}\right)$, predictive relevance $\left(\mathrm{Q}^{2}\right)$, path coefficients dan uji moderasi.

Hasil analisis data dalam uji $\mathrm{R}^{2}$ yang digunakan untuk mengukur tingkat variasi variabel independen terhadap variabel dependen, menunjukkan angka sebesar 0,547, yang artinya variasi variabel intensi berwirausaha yang dapat dijelaskan oleh variabel dukungan pendidikan, dukungan relasi dan kepercayaan diri adalah sebesar 54,7\%, sedangkan sisanya 49,5\% dijelaskan oleh variabel lain di luar model yang diajukan.

Hasil analisis data dalam uji $Q^{2}$ digunakan untuk menjelaskan hubungan dari inner model dalam penelitian. nilai $\mathrm{Q}^{2}$ adalah sebesar 0,350. Hair et al., (2014) menyatakan bahwa, konstruk eksogen memiliki relevansi prediktif untuk konstruk endogen yang dapat dinyatakan relevan untuk memprediksi model penelitian apabila memiliki nilai Q lebih dari 0 .

Hasil uji GoF yang digunakan untuk menunjukkan tingkat kecocokan model yang digunakan dalam suatu penelitian. Nilai NFI adalah sebesar 0,662. NFI adalah suatu model pengukuran yang berguna untuk mengukur model penelitian apakah fit atau tidak. Nilai NFI yang baik adalah $0-1$, jika nilai NFI semakin mendekati 0,9 atau lebih, artinya model tersebut dapat dikatakan baik (Azar \& Shafighi, 2013).

Tabel 4. Hasil Uji Path Coefficient menggunakan Bootstrapping

\begin{tabular}{|c|c|c|c|}
\hline Variabel & Path coefficient & t-statistic & $p$-value \\
\hline $\begin{array}{c}\text { Dukungan Pendidikan -> Intensi } \\
\text { Berwirausaha }\end{array}$ & 0,527 & 6,173 & 0,000 \\
\hline $\begin{array}{c}\text { Dukungan Relasi -> Intensi } \\
\text { Berwirausaha }\end{array}$ & 0,156 & 2,255 & 0,025 \\
\hline
\end{tabular}

Sumber: Output smart PLS 3, 2019

Hasil pengujian hipotesis pertama (H1) yang diperoleh variabel dukungan pendidikan menunjukkan nilai t-statistics sebesar 6,173, p-values sebesar 0,000 dan path coefficient sebesar 0,527. Nilai tersebut lebih besar dari cut-off value sebesar 1,96 dan pvalues yang lebih kecil dari 0,05 sehingga $\mathrm{H} 1$ tidak ditolak dengan path coefficient yang lebih besar dari 0 yaitu positif. Oleh karena itu, dapat disimpulkan bahwa dukungan pendidikan berpengaruh secara positif dan signifikan terhadap intensi berwirausaha. 
Hasil pengujian hipotesis kedua $(\mathrm{H} 2)$ yang diperoleh variabel dukungan relasi menunjukkan nilai t-statistics sebesar 2,225 dan p-values sebesar 0,025 dengan path coefficient sebesar 0,156. Nilai tersebut lebih besar dari cut-off value sebesar 1,96 dan pvalue yang lebih kecil dari 0,05 sehingga $\mathrm{H} 2$ tidak ditolak dengan path coefficient yang lebih besar dari 0 yaitu positif. Oleh karena itu, dapat disimpulkan bahwa dukungan relasi berpengaruh secara positif dan signifikan terhadap intensi berwirausaha.

Tabel 5. Tabel Uji Moderasi

\begin{tabular}{|c|c|c|c|}
\hline Variabel & Path coefficient & t-statistics & $p$-values \\
\hline $\begin{array}{c}\text { Kepercayaan Diri -> Intensi } \\
\text { Berwirausaha }\end{array}$ & 0,083 & 1,258 & 0,209 \\
\hline $\begin{array}{c}\text { Kepercayaan Diri -> Dukungan } \\
\text { Pendidikan x Intensi } \\
\text { Berwirausaha }\end{array}$ & $-0,169$ & 2,781 & 0,006 \\
\hline $\begin{array}{c}\text { Kepercayaan Diri -> Dukungan } \\
\text { Relasi x Intensi Berwirausaha }\end{array}$ & 0,094 & 2,049 & 0,041 \\
\hline
\end{tabular}

Sumber: Output smart PLS 3, 2019

Hasil pengujian hipotesis ketiga (H3) yang diperoleh variabel moderating effect 1 menunjukkan nilai t-statistics sebesar 2,781 dengan p-values sebesar 0,006 dan path coefficient sebesar -0,169. Nilai tersebut lebih kecil dari cut-off value sebesar 1,96 dengan p-values yang lebih kecil dari 0,05 sehingga $\mathrm{H} 3$ tidak ditolak dan path coefficient yang lebih kecil dari 0 yaitu negatif. Oleh karena itu, dapat disimpulkan bahwa kepercayaan diri memoderasi atau memperkuat secara negatif hubungan antara dukungan pendidikan terhadap intensi berwirausaha. Berdasarkan penjelasan hipotesis dalam penelitian ini dapat dijelaskan bahwa variabel moderating effect 1 pada penelitian ini adalah moderasi murni.

Hasil pengujian hipotesis keempat (H4) yang diperoleh variabel moderating effect 2 menunjukkan nilai t-statistics sebesar 2,049 dengan p-values sebesar 0,041 dan path coefficient sebesar 0,094. Nilai tersebut lebih besar dari cut-off value sebesar 1,96 dengan $p$ value yang lebih kecil dari 0,05 sehingga $\mathrm{H} 4$ tidak ditolak dan path coefficient yang lebih besar dari 0 yaitu positif. Oleh karena itu, dapat disimpulkan bahwa kepercayaan diri memoderasi atau memperkuat secara positif hubungan antara dukungan relasi terhadap intensi berwirausaha. Berdasarkan penjelasan hipotesis dalam penelitian ini dapat dijelaskan bahwa variabel moderating effect 2 pada penelitian ini adalah moderasi murni.

\section{DISKUSI}

Pengujian hipotesis pertama (H1) ini sejalan dengan penelitian sebelumnya yang dilakukan oleh Turker dan Selcuk (2009) yang menyatakan bahwa, dukungan pendidikan memiliki pengaruh positif dan signifikan terhadap intensi berwirausaha. Jika sebuah perguruan tinggi menyediakan pengetahuan yang memadai dan inspirasi untuk kewirausahaan, kemungkinan memilih karir kewirausahaan mungkin meningkat di kalangan 
kaum muda. Hal ini jelas bahwa hasil ini menegaskan peran kunci pendidikan dalam pengembangan niat kewirausahaan. (Turker dan Selcuk, 2009)

Pengujian hipotesis kedua (H2) ini juga sejalan dengan penelitian sebelumnya yang dilakukan oleh Gelaidan dan Abdullateef (2017) yang mengungkapkan bahwa, dukungan relasi memiliki pengaruh positif dan signifikan terhadap intensi berwirausaha. Ismail dkk., (2009) menyatakan bahwa, seseorang yang menerima dukungan dalam bentuk keuangan, informasi, afeksi, dan moral dari relasinya akan memungkinkan intensi mereka menjadi wirausaha semakin besar dibandingkan dengan orang yang tidak menikmati dukungan tersebut.

Berdasarkan hasil pengujian hipotesis ketiga (H3) dapat disimpulkan bahwa kepercayaan diri memoderasi secara negatif atau memperlemah hubungan antara dukungan pendidikan dan intensi berwirausaha. Hasil pengujian ini tidak sejalan dengan penelitian sebelumnya yang dilakukan oleh Turker dan Selcuk (2009) yang menyatakan bahwa, kepercayaan diri tidak memoderasi hubungan antara dukungan pendidikan dan intensi berwirausaha mahasiswa di Turkey.

Selanjutnya, berdasarkan hasil pengujian hipotesis keempat (H4) dapat disimpulkan bahwa kepercayaan diri memoderasi secara positif atau memperkuat hubungan antara dukungan relasi terhadap intensi berwirausaha. Hasil pengujian ini tidak sejalan dengan penelitian sebelumnya yang dilakukan oleh Gelaidan dan Abdullateef (2017) yang menyatakan bahwa, kepercayaan diri tidak memoderasi hubungan antara dukungan relasi dan intensi berwirausaha mahasiswa di Malaysia.

\section{PENUTUP}

Beberapa saran dari peneliti adalah sebagai berikut:

Bagi universitas, disarankan untuk dapat terus meningkatkan kualitas dukungan pendidikan kewirausahaan yang akan diberikan kepada mahasiswa. Dengan memberikan pengetahuan dan pembelajaran tentang kewirausahaan pada mahasiswa, sehingga dapat meningkatkan niat mereka untuk menjadi seorang wirausaha yang sukses karena dukungan pendidikan berpengaruh secara positif terhadap intensi berwirausaha.

Bagi universitas, disarankan untuk dapat terus mengedukasi mahasiswa akan pentingnya pendidikan kewirausahaan bagi niat berwirausaha dan kesuksesan usaha mereka, karena kepercayaan diri mahasiswa dapat memperlemah hubungan positif antara dukungan pendidikan dengan intensi berwirausaha mereka.

Bagi penelitian selanjutnya, diharapkan agar jangkauan pengambilan sampel dapat mewakili setiap wilayah yang telah ditentukan dalam penelitian, sehingga setiap responden dapat mewakili subjek penelitian dengan tepat.

Bagi penelitian selanjutnya, disarankan agar lebih diperbanyak dan ditambahkan variabel-variabel lain seperti efikasi diri, latar belakang keluarga, sikap, kreatifitas, dan motivasi yang berpengaruh terhadap intensi berwirausaha.

\section{DAFTAR PUSTAKA}

Ajzen, I. (1991). The theory of planned behavior. Organizational Behavior and Human

Decision Process, 50, 179-211. 
Baughn, C.C., Chua, B.L.and Neupert,K.E.(2006), "The normative context for women's participation in entrepreneruship: a multicountry study", Entrepreneurship Theory and Practice, Vol. 30 No. 5, pp. 687-708.

Be 'nabou, R. and Tirole, J. (2002), "Self-confidence and personal motivation", The Quarterly Journal of Economics, Voyoonl. 117 No. 3, pp. 871-915.

Bray, I., Kenny, G., Pontin, D., Williams, R. and Albarran, J. (2016), "Family presence during resuscitation: validation of the risk-benefit and self-confidence scales for student nurses", Journal of Research in Nursing, Vol. 21 No. 4, pp. 306-322.

Burns, A. C., \& Bush, R. F. (2014). Marketing Research (7th ed.). England: Pearson Education Limited.

Dell, M. S. (2008). An investigation of undergraduate student self-employment intention and the impact of entrepreneurship education and previous entrepreneurial experience. Doctor of Philosophy, School of Business University The Australia.

Dinis, A., Paço, A.F., Ferreira, J., Raposo, M. and Rodrigues, R.G. (2013), "Psychological characteristics and entrepreneurial intentions among secondary students", Education+Training, Vol. 55 Nos 8/9, pp. 763-780

Gelaidan, H.M., Abdullateef, A.O. (2017). Entrepreneurial intentions of business students in Malaysia: The role of self-confidence, educational and relation support. Journal of Small Business and Enterprise Development, 24(1), 54-67.

Gerba, D.T.(2012), "The context of entrepreneurship education in Ethiopian universities", Management Research Review, Vol. 35 Nos 3/4, pp. 225-244.

Hair, J. F., Ringle, C. M., \& Sarstedt, M. (2011). PLS-SEM: Indeed a Silver Bullet. The Journal of Marketing Theory and Practice, 19(2), 139-151.

Hamidon, S. (2012). Entrepreneurship development in Malaysian higher education: Challenges, opportunities and way forward. Hangzhou: UNESCO-APEID.

Henderson, R., \& Robertson, M. (2000). Who wants to be an entrepreneur? Young adult attitudes to entrepreneurship as a career". Career Development International, 5(6), 279-287.

Henseler, J., Ringle, C. M., \& Sinkovics, R. R. (2009). The use of partial least square path modeling in International Marketing. Advances in International Marketing, 20, 277319.

Ismail, M., Khalid, S.A., Othman, M., Jusoff, H.K., Rahman, N.A., Kassim, K.M. and Zain, R.S. (2009), "Entrepreneurial intention among Malaysian under graduates",International Journal of Business and Management, Vol. 4 No. 10, p. 54.

Kolvereid, L. and Moen, Ø. (1997), "Entrepreneurship among business graduates: does a major in entrepreneurship make a difference?", Journal of European Industrial Training, Vol. 21 No. 4, pp. 154-60.

Lafuente, M., Remesal, A. and Álvarez Valdivia, I.M. (2014), “Assisting learning in eassessment: a closer look at educational supports", Assessment and Evaluation in Higher Education, Vol. 39 No. 4, pp. 443-460.

Robb, A.M. and Fairlie, R.W. (2006), "Tracing access to financial capital among AfricanAmericans from the entrepreneurial venture to the established business", Research Conference on Entrepreneurship Among Minorities and Women.

Sekaran, U., \& Bougie, R. (2013). Research Methods for Business (6th ed.). Italy: Printer Trento Srl. 
Souritaris, V., Zerbinati, S. and Al-Laham, A. (2007), "Do entrepreneurship program raise entrepreneurial intention of science and engineering student? The effect of learning, inspiration and resource", Journal of business Venture, Vol. 22, No. 4, pp. 566- 591

Stel, A., Carree, M. and Thurik, A.R.(2005), "The effect of entrepreneurial activity on national economic growth", Small Business Economics,Vol.24 No.3,pp.311-321.

Thompson, J.L. (1999), “A strategic perspective of entrepreneurship”, International Journal of Entrepreneurial Behaviour and Research, Vol. 5 No. 6, pp. 279-296.

Turker, D., \& Selcuk, S. S. (2009). 'Which factors affect entrepreneurial intention of university students?'. Journal of European Industrial Training, 33(2), 142-159. entrepreneurship as a career". Career Development International, 5(6), 279-287.

Twibell, R. S., Siela, D., Riwitis, C., Wheatley, J., Riegle, T., Bousman, D., Cable, S., Caudill, P., Harrigan, S., \& Hollars, R. (2008). Nurses' perceptions of their selfconfidence and the benefits and risks of family presence during resuscitation. American Journal of Critical Care, 17(2), 101-111.

Yun Hee Cho, Joo-Heon Lee, (2018) "Entrepreneurial orientation, entrepreneurial education and performance", Asia Pacific Journal of Innovation and Entrepreneurship, Vol. 12 Issue: 2, pp.124-134,

Yurtkoru, S. Kuşcu, Z.K., \& Doğanay, A. (2014). Exploring the Antecedents of Entrepreneurial Intention on Turkish University Students. Procedia- Social and Behavioral Sciences, 150, 841-850 